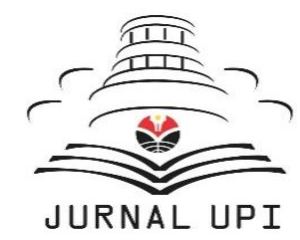

INDONESIAN JOURNAL OF APPLIED LINGUISTICS

Vol. 10 No. 2, September 2020, pp. 382-396

Available online at:

https://ejournal.upi.edu/index.php/IJAL/article/view/28610

https://doi.org/10.17509/ijal.v10i2.28610

\title{
Towards developing colloquial Indonesian language pedagogy: A corpus analysis
}

\author{
Halim Nataprawira and Michael D. Carey* \\ School of Education, University of the Sunshine Coast, Maroochydore DC, Queensland, Australia
}

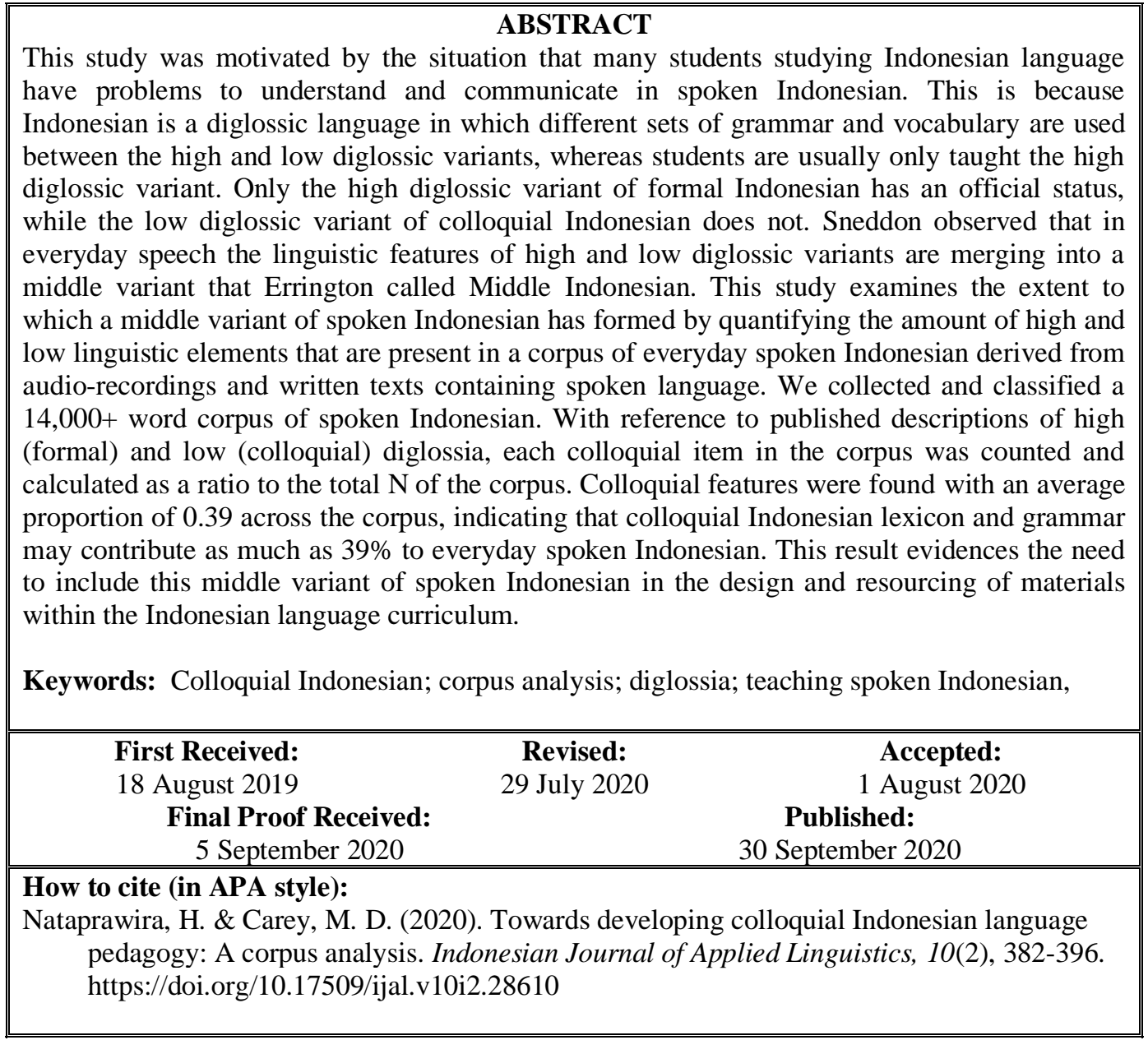

\section{INTRODUCTION}

Internationally, many students studying Indonesian as a foreign language have problems to understand and communicate in spoken Indonesian. This may be due to the lack of appropriate learning resources to teach informal spoken Indonesian to foreign learners. Coinciding with this lack of resources, a formal high diglossic variant of standard Indonesian is often misrepresented as the informal everyday spoken language of Indonesia for language teaching purposes. This is because Indonesian is a diglossic language (Errington, 1986; Sneddon, 2003a) in which different sets of grammar and vocabulary are used between the high and low diglossic variants, whereas students are usually only taught the high diglossic variant. Only the high diglossic variant of formal Indonesian (FI) has an official status, while the low diglossic variant of colloquial Indonesian (CI) does not (Smith-Hefner, 2007; Sneddon, 2003b). An understanding of the features of Indonesian diglossia is critical to redress the misrepresentation of the spoken language by Indonesian language teachers and resource developers.

Diglossia is a situation in which a single language community uses two dialects or languages. In addition to the community's vernacular, or everyday language variety (labeled

* Corresponding Author

Email: mcarey@usc.edu.au 
"L" or "low" variety), a second, highly codified variety (labeled " $\mathrm{H}$ " or "high") is used in certain situations such as literature, formal education, or other specific settings, but not used for ordinary conversation (Errington, 2014; Ferguson, 1959). The reality of the Indonesian linguistic landscape is much more complex than the diglossic paradigm that is addressed in this article when regional languages and dialects are brought into consideration (Tamtomo, 2019). This article primarily addresses the Jakartan-origin middle variant that we hypothesise has become the common contemporary spoken language of Indonesian popular culture.

Research on Indonesian diglossia was pioneered by Errington (1986) and subsequent extensive research was continued by Sneddon (2001). Linguistic descriptions have been undertaken by Nothofer (1995), Sneddon (2001, 2003, 2006), Djenar (2006, 2008), Djenar \& Ewing (2015), Tjung et al. (2006), Smith-Hefner (2007) and Kushartanti (2014). Many of these studies concentrated on the social and grammatical functions of selected lexical items. Sneddon (2003b) raised the possibility of a future merging of FI and CI into a middle variant. The gap in the research is that this merger is yet to be empirically investigated with a contemporary sample of spoken Indonesian. It is the objective of this current study, using both qualitative description and quantitative measures, to investigate Sneddon's FI-CI merging postulation. In this paper it is referred to as 'the $\mathrm{M}$ (middle) hypothesis' - that a middle variant has become the common spoken Indonesian (SI) language. To affirm the $\mathrm{M}$ hypothesis, CI must be an integral feature - alongside FI - in a corpus of informal spoken language.

Indonesian diglossia has arisen from the different Malay dialects that were spoken throughout the Malay Archipelago (Errington, 2014; Ewing, 2016; Gil, 1994; Manns, 2014). Formal Indonesian (FI) is derived from Royal Riau Malay court language which became the basis of Classical Malay literature and was well established as the language of literature by the time of European arrival in the 16th Century (Sneddon, 2003 b). There were also several varieties of Market Malays, used by commoners in everyday transactions. Some of these varieties are the antecedents of colloquial Indonesian (CI). The CI variety that is treated in this study is the CI of Jakarta which is strongly influenced by Jakarta's Malay dialect Betawi Malay (Grijns, 1991; Sneddon, 2003a). Betawi Malay itself is a form of Malay that is influenced by Sundanese, Javanese, Balinese, Hokkien Chinese and Dutch, and these language features have in turn been inherited by Jakartan CI.

The emergence of Jakarta as the capital of independent Indonesia led to the formation of a language hybrid that we call spoken Indonesian (SI) in this article, an everyday spoken language that consists of FI and CI. This SI was largely driven by the 'new Jakartans', the post-independent generation of the capital who began fusing CI Betawi linguistic features with FI (Sneddon, 2003b). The Jakartan population, the youth especially, created many new words and phrases, even though the linguistic patterns, grammar, phonology and morphology did not evolve beyond those of Betawi Malay. It has been noted that children in Jakarta and the surroundings grow up speaking a register of Indonesian that leans strongly towards CI (Kushartanti, 2014).

While CI originated in the Jakartan speech community and its surroundings, in time, due to the prominence of Jakarta as the capital city and as an exporter of culture through its command of the media and literature, it spread to other parts of Indonesia (Sneddon, 2006). For example, outside the capital Jakartan CI can be commonly heard in radio broadcasts in regional cities such as Bandung, Denpasar and Padang as young speakers in regional cities use it during inter-ethnic interactions, as an in-group code and to project youth identity (Manns, 2014).

\section{The taxonomies and coding of Indonesian diglossia}

The FI-SI-CI taxonomy in this article corresponds to Sneddon's High, (hypothesized) Middle, and Low varieties. The FI-SI-CI coding we propose is a categorization system that establishes welldefined boundaries of each variant and allows for qualitative and quantitative linguistic analysis. FI, also referred to as standard Indonesian and known in Indonesian as bahasa Baku, is the language of formal spoken and written communication, such as government protocols and news presentations. The everyday spoken language is known by Indonesians as bahasa Sehari-hari. Indonesians certainly recognise the differences between formal and informal forms and switch between the two as the situation demands. However, often in practice there is not always a clear distinction between the use of formal and informal language (Djenar \& Ewing, 2015; Sneddon, 2001). Speakers may make their informal speech somewhat more formal by incorporating some features of formal language and thus characteristics of FI are not excluded from informal conversation (Sneddon, 2001). Likewise, the formal language does not always conform to a standard form when used in social discourse. A politician may use less formal language in an unprepared speech to demonstrate his populist intentions when trying to connect to the masses. This linguistic grey zone described above by Sneddon and Djenar is considered in this article as the formal-informal spectrum of SI.

The grammar and identity of FI is well 
established and universally accepted. One problem in discussing Indonesian diglossia is the lack of universally agreed terms for the different diglossic language variants and sub-variants. The next section consolidates existing sociolinguistic terminologies into a workable coding system that allows for a systematic analysis of Indonesian diglossia.

\section{Confusion in terminology}

Firstly, it is important to clarify terminology used in relation to CI because consensus is lacking across the literature. Sneddon (2001) and Djenar \& Ewing (2015) have used the term 'informal Indonesian', and Smith-Hefner (2007) used the term 'spoken informal Indonesian', while Manns (2014) used the term 'Jakartan Indonesian'. Djenar (2006, p. 22) noted that there are many other terms used at different times by different writers in regard to the colloquial variety of Indonesian including bahasa tak baku "non-standard language", bahasa informal "informal language", bahasa gaul "social language", bahasa ABG "teen language", bahasa remaja "youth language”, 'informal Jakartan Indonesian' and 'colloquial Jakartan Indonesian' (Kushartanti, 2014; Sneddon, 2006). Our view is that the terms mentioned above are often interchangeable and, in some cases, sub-variants of CI. The most common recent confusion amongst student researchers of Indonesian language is that bahasa gaul (social language) has been mistaken as CI. In this article, we classify bahasa gaul as a sub-variant of CI because bahasa gaul does not have different linguistic features to $\mathrm{CI}$, aside from some extra lexical items created by younger speakers. SmithHefner (2007) stated that bahasa gaul functions within the linguistic parameters of CI with additional fad words. Like all living languages, it is constantly changing as new words or expressions become popular and fall out of use. At this point, it is worth clarifying the distinction between CI and SI. CI linguistic features pre-existed in Betawi Malay. SI on the other hand is a modern hybrid that we propose to be a derivative of both CI and FI. SI possesses no linguistic features of its own but is dependent on those of CI and FI. The presence of CI linguistic features in SI defines SI's function as an informal language variant.

This study analyses a corpus of everyday spoken Indonesian language derived from transcribed audio-recordings, such as interviews and films, and written texts containing spoken language, such as novels and short stories. Linguistic features were classified at the lexical and sub-lexical level as CI, FI, or neutral lexemes, and transcribed using the International Phonetic Association's (IPA) set of phonetic symbols. These linguistic features included lexis, phonology, morphology and semantics. The following questions guide this research:
1. In what ways are the linguistic features of CI unique and how can they be identified and described?

2. How prevalent are the linguistic features of CI in a corpus of everyday spoken Indonesian?

\section{METHOD}

A corpus-based analytic approach was the chosen research method because corpus-based research assumes the validity of linguistic forms and structures derived from linguistic theory (Biber, 2015). The primary goal of this research approach is to analyse the systematic patterns of variation and use for pre-defined linguistic features. The approach allowed us to ascertain how, and to what extent, pre-defined linguistic features form part of everyday spoken Indonesian. Previous descriptions of CI (Djenar, 2008; Djenar \& Ewing, 2015; Kushartanti, 2014; Sneddon, 2006;) were used to classify the features of CI. These non-FI linguistic features were used to inform the qualitative description of CI using the IPA. Each CI item in the corpus was counted and quantitatively measured as a ratio in each data sample and to the total $\mathrm{N}$ of the corpus. Lexicon that are 'neutral', namely uninflected base words, are not counted as CI and make up the proportion of the remaining total (neutral + FI). The $\mathrm{M}$ hypothesis of Indonesian diglossia is expressed as a null-hypothesis H0: $\mathrm{CI} / \mathrm{SI}=0$ and as an alternative hypothesis $\mathrm{H} 1$ : CI/SI $>0$. The $\mathrm{SI}$ in these hypotheses represents the entire $\mathrm{N}$ of the corpus of everyday language and the CI/SI ratio is used as a proportional measure to gauge the extent to which CI linguistic features form part of the everyday informal spoken Indonesian.

\section{Data samples}

The corpus used in this study is a sample of realworld language data and is therefore assumed to be representative (Chapman \& Routledge, 2009; Stubbs, in Davies \& Elder, 2008). The corpus was assembled and is available online (Nataprawira, 2017). Samples have been obtained from interview recordings with native Indonesian speakers compiled by Sneddon (2006) as well as samples of spoken texts from media, internet content, billboard advertisements and audio-visual media such as TV shows and films (Table 1).

The data samples were analysed as raw data, meaning that they were not modified from their original form. Audio-visual data samples were obtained from YouTube. The corpora were collected by transcribing parts of dialogues of films, comedies and TV shows. These text samples were selected because they provide a range of discourse registers (field, mode and tenor), including some spontaneous language use (comedies) that represents naturally occurring spoken dialogue. 
Examples of audio-visual data sources include dialogues from the Opera Van Java comedy show, parts of films such as Buaya Gile and Jakarta Undercover. The billboard data samples were obtained from photographs of billboards. Table 1 shows the number of data samples, the number of lexical items each sample contained and the number of CI lexical items in each sample contained and the number of CI lexical items in each category.

As our research design used descriptive statistics, a measure of statistical power for the number of word tokens collected in the corpus was not required. Instead, we selected word tokens from a range of text types and spoken registers (14711 words across 48 data samples) to obtain a valid representation of SI language (Table 1).

\section{Data analysis}

Three methods of data analysis were used after collecting the raw corpus data (Figure 1).

Table 1

SI Corpora Data Samples

\begin{tabular}{llll}
\hline Data sample categories & $\boldsymbol{N}$ & SI & CI \\
\hline Recorded interviews and conversations & 6 & 6408 & 2130 \\
Contemporary literature & 16 & 4603 & 1298 \\
Audio-visual media & 14 & 3626 & 1745 \\
Billboard advertisement & 12 & 74 & 27 \\
\hline & $\sum \boldsymbol{n}=48$ & $\sum \mathbf{S I}=14711$ & $\sum \mathbf{C I}=5200$ \\
\hline
\end{tabular}

Figure 1

The Mixed-Method Design of This Research

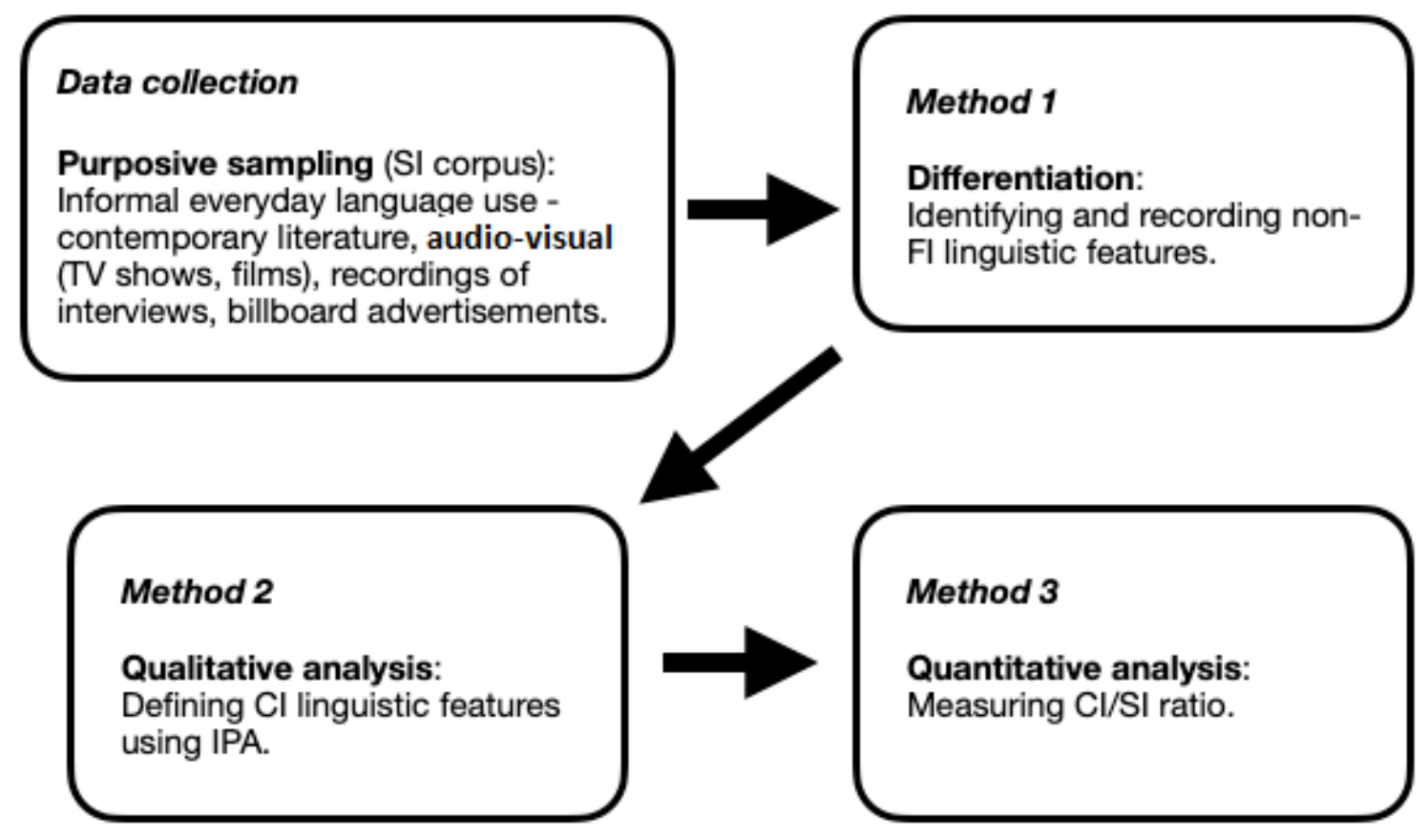

To address the research questions, a mixedmethod design consisting of qualitative and quantitative analysis was chosen. The qualitative component defines the CI linguistic features in the SI corpora (research question 1), which in turn are quantitatively measured to obtain an indication of the level of CI frequency and prevalence in SI (research question 2).

\section{Method 1 - Differentiation: Identifying and collecting non-FI linguistic features.}

The differentiation method used to investigate if CI was present in the SI corpus involved the identification of linguistic features that were not FI.
In this process, lexical items were first classified as FI or non-FI through a broad analysis of the phonological, morphological and semantic features of lexical items in the corpus. The description of FI in this study followed Sneddon (1996, 2000), Quinn (2001) and Djenar (2003).

\section{Method 2 - Qualitative analysis: Defining CI linguistic features using IPA.}

Using the findings from Method 1, the CI linguistic features were categorized more discretely using the IPA. We referred to previous use of IPA in classifying the features of CI employed by Grijns (1981) in his study of variations in Betawi Malay. 
The morphological analysis follows the common system used to describe affixation in Indonesian such as that employed by Boellstorff (2002). Using various existing descriptions of $\mathrm{CI}$ that have been provided by previous researchers, we devised guidelines to identify CI linguistic features. The guidelines included several indicators. Examples of these indicators are provided in the section Qualitative results: CI in SI corpus:

1. Syntactical ellipsis is a common feature in daily speech (Sneddon, 2006).

2. Morphological variations that are different from FI (Fan, 1990; Kushartanti, 2014).

3. The phonological divergences from FI (Kushartanti, 2014).

4. Elisions and allomorphy (Kushartanti, 2014; Sneddon, 2006).

5. Alternative lexical items not present in FI (Djenar \& Ewing, 2015; Sneddon, 2006).

6. Variation in semantic properties that fall outside of FI grammar (Djenar, 2008; Sneddon, 2006).

\section{Method 3 - Quantitative analysis: Measuring the CI/SI ratio.}

The aim of this research was to establish quantitatively the number of CI items in the SI corpus. Descriptive statistics were applied to test the null hypothesis that the CI/SI ratio in the corpus is equal to zero; $\mathrm{H} 0: \mathrm{CI} / \mathrm{SI}=0$ and the alternative hypothesis that the $\mathrm{CI} / \mathrm{SI}$ ratio in the corpus is greater than zero; $\mathrm{H} 1$ : CI/SI $>0$.

\section{FINDINGS AND DISCUSSION \\ Qualitative results: CI in SI corpus}

The first method of data analysis indicated that there was a substantial amount of non-FI linguistic features in the SI corpus. These linguistic features have sub-components which consist of: non-FI lexicon, non-FI morphological features, non-FI null parameter / ellipsis, non-FI elisions, non-FI phonological realizations and non-FI semantic properties. The presence of CI and FI in the SI corpora supports Sneddon's (2006) assertion of the existence of a middle variant in spoken Indonesian. Concurrently, the notion that a pure form of FI is used as an informal spoken language can be rejected. CI can be positively verified to be an integral part of the everyday language. The second method was then applied which involved a discrete classification of non-FI items using the IPA. The result is a detailed description of CI that demarcates the diglossic boundary between CI and FI. CI consists of CI lexicon, CI morphological features, null parameter / ellipsis, elisions, CI phonological realisations and CI semantic properties. The examples below provide a summary of CI that was identified in contrast to the FI form; for a complete analysis, see Nataprawira (2017):

1. Word class ellipsis/null elements $\varnothing$ in the syntax of daily speech. Three notable common null elements in informal Indonesian syntax are

a. The personal pronoun ellipsis in structures such as:

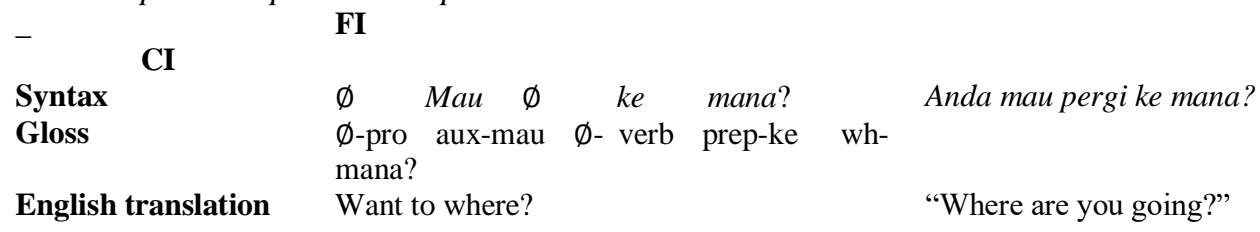

$\begin{array}{lllll}- & \text { FI } & & & \\ \text { Syntax } & \varnothing & \text { Gak } & \text { mau. } & \text { Saya tidak mau. } \\ \text { Gloss } & \emptyset \text {-pro } & \text { neg-Gak } & \text { aux-mau } & \text { "I don't want to" } \\ \text { English translation } & \text { I } & \text { not } & \text { want } & \end{array}$

b. The adalah copula ellipsis in nominative structures such as:

- $\quad$ FI

Syntax CI Bapak $\emptyset$ kepala desanya di sini. Bapak adalah kepala desanya di sini.

Gloss pro-Bapak $\emptyset$-cop NP-kepala desaDET-nya prep-di NP-sini

English translation Mister head village-the in here. "He is the village head here."

c. The common null element parameter of the predicate pergi in phrases such as:

- FI

Syntax CI $\quad$ Lagi $\varnothing$ ke mana?

Gloss $\quad \emptyset$-pro aux-lagi $\emptyset$-verb prep-ke wh-mana?

English translation -ing to where?

Anda sedang pergi ke mana?

"Where are you going?" 
2. Morphological features. Some scholars regard these following phonemic forms as allomorphy of the active me- prefix, but they could possibly also be independent morphemes inherited from Sundanese, Javanese and Balinese.
a. ' $m$ ' $(/ m /)-X$
CI
Lexical item
FI
Make momakai
Syntax gloss
$\mathrm{m}$-(p)-ake
English gloss/translation to use; to wear to wear"
b. ' $n$ ' $(/ n /)-X$
Note that the base word pakai this example also undergoes a phonological shift to [pake].
CI
Lexical item
FI
CI phonology/morphology gloss
English gloss/translation
Nangkep
$\mathrm{n}$-(t)-angkəp
Catch
mənangkap
"to catch"
Note that a phonological change also takes place in the base word tangkap $\Rightarrow$ tangkap.

c. 'ng' (/y/) $X \&$ 'nge' $(/ y \partial /)-X$

The example ngopi also demonstrates the predication of a NOUN $X$ that does not occur in FI:
_CI
Lexical item
FI
CI phonology/morphology gloss
Ngopi
y-(k)-opi
minum kopi
English gloss/translation
drink coffee
CI
Lexical item
FI
Ngirim məngirim
CI phonology/morphology gloss
English gloss/translation
$\mathrm{n}$-(k)-irim
Send "to send"
CI
Lexical item
FI
Ngecek məməriksa
CI phonology/morphology gloss
English gloss/translation
yə-cek
"to check"

"to drink coffee"

d. $X^{\prime}-i n^{\prime}(/-i n /)$

This morph replaces both FI's predicate suffixes '-kan' and '-i'. It encompasses all the grammatical functions that these FI suffixes impart (accusative, dative-benefactive, accusativecausative):

Lexical item

CI phonology/morphology gloss

English gloss/translation

\section{CI}

Lexical item

CI phonology/morphology gloss

English gloss/translation
FI/pragmatics

bikinin (mem)buatkan [+benefactive]

bikin-in

make "to make something for somebody"

\section{FI/pragmatics}

benerin (mem)bənarkan [+causative]

bən-ə-r-in

fix "to fix/correct something"

e. '-ny' (/n/)-X

Like the $/ \mathrm{y} /$ phoneme, $/ \mathrm{n} /$ is also an allomorphic active prefix of me- (or a proper morph) that operates on base words with first letters 'c' and 's'. Some examples include:

$$
\text { CI }
$$

Lexical item

CI phonology/morphology gloss

English gloss/translation

\section{CI}

Lexical item

CI phonology/morphology gloss

English gloss/translation
FI

nyuci
$\mathrm{j}$-(c)-uci
wash

məncuci

"to wash"

FI

nyebar

$\mathrm{n}$-(s)-əbar

spread mənyəbar

"to spread"

f. 'ng' (/y/) - X'-in' (/-in/) \& 'nge' (/yə/) - X'-in' (/-in/)

This is the active form of $1.3 \mathrm{~b}$. It is the CI variation of FI's me- $\mathrm{X}-\mathrm{kan}$ and me- $\mathrm{X}-\mathrm{i}$. The example ngapain is a predication of WH- lexical item apa and has two semantic values:
CI
FI/pragmatics

Copyright @ 2020, authors, e-ISSN: 2502-6747, p-ISSN: 2301-9468 


$\begin{array}{lll}\text { Lexical item } & \text { ngapaiin } & \begin{array}{l}\text { sedang apa; untuk apa } \\ \text { [+interrogative] }\end{array} \\ \begin{array}{l}\text { CI phonology/morphology gloss } \\ \text { English gloss/translation }\end{array} & \begin{array}{l}\text { y-wh-apa-in } \\ \text { what-ing?"; "What for?" }\end{array} & \text { "what are you doing?"; "What for?" } \\ \text { CI } & \text { FI } & \\ \begin{array}{l}\text { Lexical item } \\ \text { CI phonology/morphology gloss } \\ \text { English gloss/translation }\end{array} & \begin{array}{l}\text { ngebeliin } \\ \text { yə-bəli-in }\end{array} & \text { mombəlikan [+benefactive] } \\ & \text { buy } & \text { "to buy something for somebody" }\end{array}$

g. '-ny' (/n/)- $X$ '-in' (/-in/)

This is the active form of $1.3 \mathrm{c}$. It is the CI variation of FI's me-X-kan and me-X-I for base words with first letters 'c' and 's'. Some examples are: nyədiain, nyariin,
CI
Lexical item
FI
CI phonology/morphology gloss
English gloss/translation
nyediain
$\mathrm{n}$-(s)- ədia-in
prepare
mənyədiakan [+benefactive]
"to prepare something for somebody"

h. 'ke-' (/ko-/) $X^{\prime}$-an'/-an/ include:

These are the alternative CI [+excessive] adverbial marker to FI's adverb terlalu. Examples
CI
FI
Lexical item
CI phonology/morphology gloss
English gloss/translation
kegedean
kə -gəde-an
too large
tərlalu bəsar
"too large"

i. $\quad X^{\prime}$-an'/-an/

This affixation is a CI alternative to the FI adverb lebih [+comparative]:
_CI
FI
Lexical item
bagusan
ləbih bagus
CI phonology/morphology gloss
bagus-an
nicer; better
"nicer, better"

3. Elisions, allomorphy and phonological variations different to FI:

a. Elision of first letters 's' and ' $h$ ' in some common words

\begin{tabular}{|c|c|c|}
\hline CI & FI & \\
\hline Lexical item & ama & Sama \\
\hline CI phonology/morphology gloss & (s)-ama & \\
\hline \multirow[t]{2}{*}{ English gloss/translation } & With & "with" \\
\hline & CI & FI \\
\hline Lexical item & abis & Habis \\
\hline CI phonology/morphology gloss & (h)-abis & \\
\hline English gloss/translation & Finish & "finished" \\
\hline
\end{tabular}

b. Elision of prefix me-(or $/ m /$-X allomorphy) in active verbs with first letter ' $p$ '
CI
FI
Lexical item
make məmakai
CI phonology/morphology gloss (p)-m-ak-e
English gloss/translation "to use"

c. Phonetic realisation [e], [a] or [ع] - in place of the second syllable ' $a$ ' vowel in the /a/ phoneme
_CI
Lexical item
FI
CI phonology/morphology gloss
English gloss/translation
item
hitam
(h)-it-ə-m
black
"black"

d. Phonetic realisation [e], [a] or [c] - in place of the second syllable ' $a$ ' vowel in place of /ail diphthong:
Lexical item
FI
Lexical item Make
məmakai
Chonology/morphology gloss
English gloss/translation
(m)-ak-e
Use "to use" 
e. The [o] phone substitute for ' $u$ ' vowel:
CI
Lexical item
FI
CI phonology/morphology gloss s-o-rga
English gloss/translation Heaven
Surga
"heaven"
f. The [o] phone substitute for /au/ diphthong:

$\begin{array}{lll}\text { CI } & \text { FI } & \\ \text { Lexical item } & \text { ijo } & \text { hijau } \\ \text { CI phonology/morphology gloss } & \text { (h)-ij-o } & \\ \text { English gloss/translation } & \text { green } & \text { "green" }\end{array}$

4. An existing array of alternative lexical features different to FI, which is often preferred in speech rather than the FI variants (see Table 2).

Table 2

Lexical Features Different to FI

\begin{tabular}{lll}
\hline CI & FI & Gloss \\
\hline Enggak/gak & tidak & "no, do not" \\
Cuma & hanya & "only" \\
pake VP segala? & kenapa harus VP? & "why VP" \\
Mendingan & lebih baik & "it is better to..." \\
Pengen & ingin, mau & "to want" \\
\hline
\end{tabular}

5. The frequent use of discourse particles that are absent in FI as can be seen in Table 3 .

Table 3

FI Absent Discourse Particles

\begin{tabular}{ll}
\hline CI & Pragmatics \\
\hline Kok & [+interrogative] \\
Deh & [+agreement] \\
Sih & [+affirmative] \\
Dong & [+request +affirmative] \\
Loh & [+interrogative] \\
Mah & [+declarative] \\
Nah & [+affirmative] \\
\hline
\end{tabular}

6. The common use of tag questions constructions:
_CI
FI
Syntax
Bagus nggak?
CI phonology/morphology gloss adj-bagus neg/tag-nggak?
English gloss/translation
Good not?
Bagus atau tidak?
"Is it good?"
CI
FI
Syntax
Lucu kan?
adj-lucu tag-kan?
CI syntax gloss
English gloss/translation
Funny right?
Lucu benar?
"Funny wasn't it?"

7. Variation in semantic properties of Indonesian lexica which are not traditionally recognised in prescriptive FI grammar. Some examples are provided in Table 4.

Table 4

Indonesian semantic properties of Indonesian lexica

\begin{tabular}{|c|c|c|}
\hline Lexical item & CI & FI \\
\hline Jalan & [+V] (" to go") & [+N] ("street"); [+V] ("to walk) \\
\hline Buat & [+prep] (" for") & {$[+\mathrm{V}]$ ("to make") } \\
\hline Biar & {$[+\mathrm{CP}]$ ("so that") } & [+V ] ("to let be") \\
\hline Mau & [+aux +tense] ("will") & [+aux + modal] ("to want") \\
\hline Suka & [+aux +tense] ("used to do") & [+aux + modal] ("to like") \\
\hline Pada & [+pronominal plural marker] & [+prep] ("on, at") \\
\hline
\end{tabular}

\section{Quantitative results: CI/SI}

The third quantitative method of analysis involved counting every lexical item with CI markings in each of the data sample in the corpus and 
statistically analysing these in terms of the CI/SI corpora ratio. SPSS produced an overall mean CI/SI ratio of 0.39 . The overall mean result of $\mathrm{CI} / \mathrm{SI}$ ratio at 0.39 means that $\mathrm{H} 0: \mathrm{CI} / \mathrm{SI}=0$ can be rejected and that $\mathrm{H} 1: \mathrm{CI} / \mathrm{SI}>0$ can be accepted.

Figure 2 illustrates the spread of each of the data samples as a CI/SI ratio. This is presented for the reader to provide a visual representation of the ratio for all corpora in their data set categories (AV: Audio- Visual; BB: Billboard; LIT: Literature; RI: Recordings of Interviews). Figure 2 shows that most data samples contained CI below 0.39, while most data samples containing $\mathrm{CI}$ above 0.39 ratios are only found in the AV and BB categories.
Interestingly, while the overall CI ratio in the RI category in this study is below 0.39, the RI data samples compiled by Sneddon (2006), show a much higher individual CI word count usage in comparison to the FI equivalent as shown in Table 5.

\section{Correspondence analysis and the formal-informal spectrum}

The distribution of the mean ratios for each data set (Table 6) shows that most of the data sets fall within the $0.2-0.7$ range with the 0.3-0.49 dimension holding the most entries. There were only three data sets that fell within the $<0.2$ and $>0.7$ dimensions.

Figure 2

All Data Sets

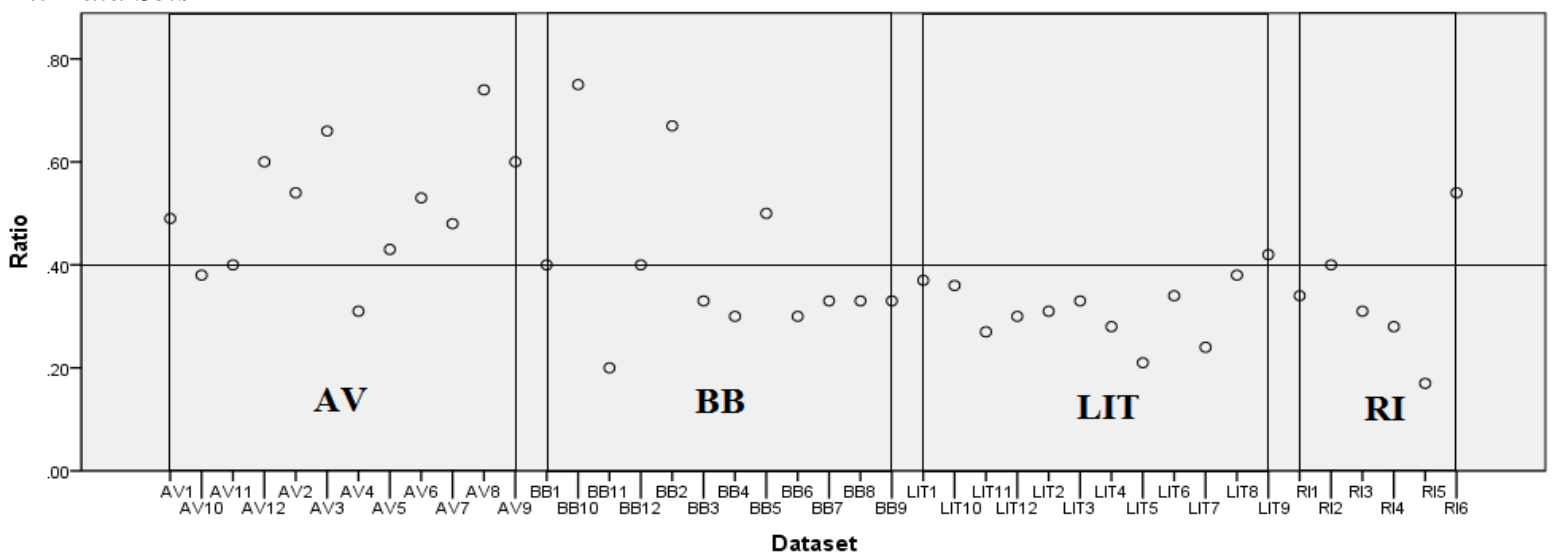

Table 5

Sneddon's Individual CI Word Count in the RI Category

\begin{tabular}{lcl}
\hline CI lexical item & $\begin{array}{c}\text { Percentage } \\
\text { vis-à-vis FI equivalent }\end{array}$ & FI equivalent \\
\hline Aja & $98.8 \%$ & saja \\
Udah & $96 \%$ & sudah \\
-in suffix & $70.4 \%$ & $-k a n /-i$ suffix \\
sama/ama & $84.6 \%$ & oleh \\
lagi $($ aux $)$ & $98.9 \%$ & sedang \\
bakal & $46.1 \%$ & akan \\
nggak/kagak/ndak & $97.9 \%$ & tidak \\
gua/gue & $91.8 \%$ & saya/aku \\
cuma(n) & $95.9 \%$ & hanya \\
banget/amat & $95.3 \%$ & sangat/sekali \\
Entar & $62.4 \%$ & nanti \\
Gimana & $94.9 \%$ & bagaimana \\
Kayak & $84 \%$ & seperti \\
pengen/kepengen/pingin/kepingin & $97.9 \%$ & ingin \\
(ng)omong & $93.9 \%$ & bicara/berbicara \\
Gede & $88.6 \%$ & besar \\
\hline
\end{tabular}

Table 6

Correspondence Analysis of All Data Sets

\begin{tabular}{lccccc}
\hline & \multicolumn{5}{c}{ Dimensions = CI/SI Ratio } \\
\hline BB $\mathrm{n}=12$ & $<0.2$ & $0.2-0.29$ & $0.3-0.49$ & $0.5-0.7$ & $>0.7$ \\
LIT $\mathrm{n}=16$ & & 1 & 8 & 2 & 1 \\
$\mathrm{AV} \mathrm{n}=14$ & 7 & 1 & 7 & 5 & 1 \\
RI $\mathrm{n}=6$ & 1 & 1 & 3 & 1 & 0.17 \\
\% of corpus & 0.02 & 0.21 & 0.56 & 0.04 \\
\hline
\end{tabular}

(BB: Billboard; LIT: Literature; AV: Audio-visual; RI: Recordings of Interviews) 
Indonesian linguistics and sociolinguistics form part of a shifting paradigm in the understanding of the spoken Indonesian language and subsequently changes in the teaching and learning of Indonesian language. A practical outcome of this research is the development of an SI language description which may inform the inclusion of CI in Indonesian language teaching materials to benefit students studying Indonesian as a foreign language.

Research suggests that utilising authentic texts in second language acquisition aides in developing native speaker competency (Gilmore, 2007). Many language learning texts that are created by publishers often do not reflect real-life language usage. Explicit teaching and learning of CI can provide explanations of the hitherto insufficiently understood CI lexis, speech acts, semantics and pragmatics, and allow for Indonesian language teachers to understand and utilise more authentic sources (e.g., contemporary real-life materials from $\mathrm{TV}$, internet and films) as teaching resources.

The findings of this study lay the linguistic foundation for the development of a colloquial spoken Indonesian pedagogy. It is outside the scope of this article to detail this colloquial spoken Indonesian pedagogy here, but the reader can find such detail in the unpublished Doctoral thesis on which this paper is based (Nataprawira, 2017). For future publications on this subject, the authors intend to provide pedagogic models on how to teach and learn colloquial spoken Indonesian. Language aspects to include are authentic texts featuring common native speaker speech acts and explicit analysis of spoken lexis, collocation and intonation, and their semantic and pragmatic implications.

\section{REFERENCES}

Biber, D. (2015). Corpus-based and Corpus-driven analyses of language variation and use. In B. Heine \& H. Narrog, (Eds.), The Oxford handbook of linguistic analysis (2nd ed.). Oxford University Press.

Boellstorff, T. (2002). Ethnolocality. The Asia Pacific Journal of Anthropology, 3(1), 24-48. https://doi.org/10.1080/1444221021000170619 6

Chapman, S., \& Routledge, C. (Eds.) (2009). Key ideas in linguistics and the philosophy of language. Edinburgh University Press.

Davies, A., \& Elder, C. (2008). The handbook of applied linguistics. Blackwell Publishing.

Djenar, D. N. (2003). A student's guide to Indonesian grammar. Oxford University Press.

Djenar, D. N. (2006). Patterns and variation of address terms in colloquial Indonesian. Australian Review of Applied Linguistics, 29(2), 16 https://doi.org/10.1075/aral.29.2.07dje

Djenar, D. N. (2008). On the development of a colloquial writing style: Examining the language of Indonesian teen literature. Bijdragen tot de Taal-, Land-en Volkenkunde, 164(2/3), 238.

https://doi.org/10.1163/22134379-90003658

Djenar, D. N., \& Ewing, M. C. (2015). Language varieties and youthful involvement in Indonesian fiction. Language and Literature, 24(2), 108-128. https://doi.org/10.1177/0963947015573387

Errington, J. (1986). Continuity and change in Indonesian language development. The Journal of Asian Studies, 45(2), 329-353. https://doi.org/10.2307/2055846

Errington, J. (2014). In search of Middle Indonesian: Linguistic dynamics in a provincial town. In G.V. Klinken, \& , W. Berenschot. (Eds.), In Search of Middle Indonesia (pp. 199-219). Brill.

Ewing, M. C. (2016). Localising person reference among Indonesian Youth. In Z. Goebel, D. Cole, \& H. Manns (Eds.), Margins, hubs, and peripheries in a decentralizing Indonesia (pp. 26-41). Tilburg University.

Fan, L. Y. (1990). Speak standard Indonesian: A beginner's guide. Times Books International.

Ferguson, C. A. (1959). Diglossia. Word, 15, 325340.

https://doi.org/10.1080/00437956.1959.116597 02

Gil, D. (1994). The structure of Riau Indonesian. Nordic Journal of Linguistics, 17(2), 179-200. https://doi.org/10.1016/b0-08-044854-2/045946

Gilmore, A. (2007). Authentic materials and authenticity in foreign language learning. Language Teaching, 40(2), 97-118. https://doi.org/10.1017/s0261444807004144

Grijns, C. D. (1981). Jakarta speech and Takdir Alijahbana's plea for the simple Indonesian word-form. In N. Phillips \& K. Anwar (Eds.), Papers on Indonesian Languages and Literature (pp. 1-34). School of Oriental and African Studies.

Grijns, C. D. (1991). Kajian bahasa MelayuBetawi. PT Pustaka Utama Grafiti.

Kohler, M., \& Mahnken, P. (2010). The current state of Indonesian language education in Australian schools. Education Services Australia.

Kushartanti, B. (2014). The acquisition of stylistic variation by Jakarta Indonesian children. LOT Trans 10.

Manns, H. (2014). Youth radio and colloquial Indonesian in urban Java. Indonesia and the Malay World, 42(122), 43-61. https://doi.org/10.1080/13639811.2014.876156

Nataprawira, H. (2017). Recognising the sociolinguistic reality of spoken Indonesian: A corpus and usage analysis of a middle 
diglossic variant. [PhD thesis, University of the Sunshine Coast]. USC Australia Research Bank.

https://research.usc.edu.au/discovery/fulldispla y?context=L\&vid=61USC_INST:ResearchRep ository\&search_scope=ResearchETD\&tab=Re search\&docid=alma99450901402621

Nothofer, B. (1995). The history of Jakarta Malay. Oceanic Linguistics, 34(1), 86-97. https://doi.org/10.2307/3623113

Quinn, G. (2001). The learner's dictionary of today's Indonesian. Allen \& Unwin.

Smith-Hefner, N. (2007). Youth language, gaul sociability, and the New Indonesian middle class. Journal of Linguistic Anthropology, 17(2), 184-203. https://doi.org/10.1525/jlin.2007.17.2.184

Sneddon, J. N. (1996). Indonesian reference grammar. NSW, Allen \& Unwin.

Sneddon, J. N. (2000). Understanding Indonesian grammar. Allen \& Unwin.

Sneddon, J. N. (2001). Teaching informal Indonesian: Some factors for consideration. Australian Review of Applied Linguistics, 24(2), 81-95. https://doi.org/10.1075/aral.24.2.06sne

Sneddon, J. N. (2002). Variation in informal Jakartan Indonesian: A quantitative study. Paper presented at the Ninth International Conference on Austronesian Linguistics, Canberra, Australia.

Sneddon, J. N. (2003a). Diglossia in Indonesian. Bijdragen tot de Taal-, Land-en Volkenkunde, 159(4), 519-549. https://doi.org/10.1163/22134379-90003741

Sneddon, J. N. (2003b). The Indonesian language: Its history and role in modern society. UNSW Press.

Sneddon, J. N. (2006). Colloquial Jakartan Indonesian. Pacific Linguistics.

Tamtomo, K. (2019). The creation of monolanguaging space in a krámá Javanese language performance. Language in Society, 48(1), 95-124. https://doi.org/10.1017/s0047404518001124

Tjung, Y., Cole, P., \& Hermon, G. (2006). Is there pasif semu in Jakarta Indonesian? Oceanic Linguistics, 45(1), 64-90. https://doi.org/10.1353/ol.2006.0009 


\section{APPENDIX}

\section{Data sample BB10}

The following are the data samples outside the $<0.2$ and $>0.7$ correspondence analysis range. The first two samples have a CI content $<0.2$ and the last one $>0.7$. These samples demonstrate how field and tenor can affect language use in the formal-informal spectrum.

BB10 is an advertisement for after school lesson preparing students for the national and general exams. The word count only included the sentence Dapetin Suksesmu Di Sini ("Find Your Success Here") an advertising slogan appealing directly to the target audience. The pragmatic function of this sentence might explain the use of the CI item Dapetin, employing language of familiarity to attract student customers. The general information about the course on the banner - all in FI - is not counted, as it is not representative of direct speech or dialogue.

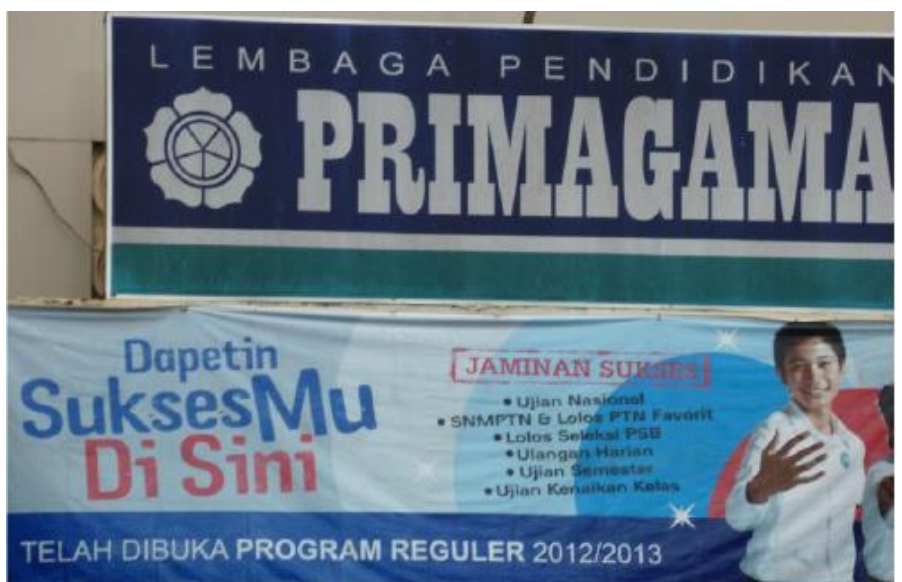

Depatin SuskesMu Di Sini. Dapetin - CI morphology of -in suffix

Total word count: 5 . CI words: 1

\section{Data sample RI15}

RI15 is the transcript of a recorded interview between the interviewee R, a 47-year-old academic and the 23year-old interviewer Yuli. The interview took place in R's office. The tenor, a senior academic conversing with the younger interviewer in a somewhat formal setting - R's office, would have informed the choice of more formal language, despite it being a non-formal interview. CI items (in italics) still peppered the conversation used by both speakers. Source: Sneddon, J. N. (2006).

Two speakers:

A: R, 47, female, member of academic staff, Atma Jaya University

B: Yuli, 23, female, interviewer and recorder

The interview was in R's office on 10 January 2001. The opening is somewhat formal and courteous. The interviewee speaks rather slowly and quite fluently. Her story is at times somewhat discursive and not always chronological.

B: Selamat pagi. Ah sekarang saya ada di ruangannya Ibu RJ, kepala PBB yang baru. Aa Slamat pagi, Bu R.

A: Selamat pagi Yulianti.

B: Apa kabar Bu?

A: Eh, baik-baik aja tuh. Gimana?

$\mathrm{B}$ : Ah gini Bu. Saya mo interview Ibu ni. Bisa nggak Ibu cerita kira-kira dari kehidupan Ibu dari kecil sampe sekarang?

A: Am gini Yulianti. Saya itu kan lahir taun lima puluh tiga, ya. Lima pulu tiga itu, skarang sudah umur empat pulu tuju tahun ya? Udah, udah tua, uda nenek-nenek.

Lalu, saya mulai di- saya dilahirkan dari sua- satu keluarga yang sangat besar dengan orang tua yang punya anak dua belas anak. Lalu ayah saya itu seorang miskin ya, dalam arti, aa saya datang dari keluarga miskin. Ayah ibu saya itu, Ibu saya tukang ju- tukang kue. Malu kan? Hanya...

B: Nggak pa-pa.

A: Tukang kue keliling, gitu ya. Tukang kue keliling dan ayah saya itu juga aa mungkin kalo sekarang itu tukang loak, ya? Bilangnya ya? Yang di pinggir jalan itu ya. Lalu dia punya anak dua belas. Lalu a... setiap anak itu diajar untuk mandiri. Untuk sendiri-sendiri pokoknya cari makan, gitu yah. Supaya survive. Tapi ada 
satu hal yang saling men- yang sampe skarang saya masih inget bahwa orangtua saya mengatakan bahwa kepandaian itu tidak akan hilang. Jadi dia katanya ee sekolah, begitu. Apapun harus sekolah, begitu. Sehingga ee kami mendapat contoh dari yang paling besar, jadi anak yang paling besar, skarang dia adalah ginekolog ee spesialis kebidanan, dan dia sukses sekali ya. Ee dia senior begitu ya? Bekas kepala rumah sakit Cirome, Cirebon, dan sebagainya. Dia tantara ya. Karna memang di tantara itu kan dikasi makan ya, dikasi uang lauk pauk dan sebagainya. Jadi dia kuliah di UI, itu menjadi panutan kita semua. Yang paling besar ee jadi panutan. Dia kuliah di UI dan kami tinggal di Bogor. Dan dia harus naek kereta api untuk ke UI, san setelah ee sampe, sampe dia lulus itu kami masih miskin, nggak punya apa-apa. Dia paling-paling naik sepeda, gitu ya. Lalu ee kalo saya liat fotonya tuh saya sedih beneran, karna dia begitu kurusnya, kecilnya begitu ya, tapi dia pengen selesei. Begitu dia selesei dia masuk ke ee dinas militer ya. Dinas militer, waktu itu dia ditempatkan di Kalimantan, kalo nggak salah. Di Kalimantan itu dengan penuh penderitaan dia lalui, dan dia kembali ke Jakarta. Ah saya masi kecil. Saya anak kesembilan. Anak kesembilan dari dua belas besodara. Jadi waktu dia kembali itu, adik-adiknya ikut dengan dia, walopun dia masih minim sekali. Dia baru lulus, baru selesei, datang ke Jakarta, keadaan masih nggak punya tapi kita ikut, nebeng, gitu yah? Dibagi-bagi, ade-adenya tu dibagi. Ada yang ikut sana, ada yang ikut sini, gitu. Saya tu termasuk ikut dia. Ee dia tuh tantara. Jadi waktu, saya inget skali, waktu saya sudah mahasiswa, aa nanti kita flashback ke blakang ya? Waktu saya mahasiswa, itu ada peristiwa Malari, jadi dia punya... apa? Dia ada mobil combi gitu, jelek sekali ya, masuk di Kramat, oo dilempari batu oleh siapa nggak ngerti. Dan dia begitu sedihnya karna dia pecah itu kacanya gitu. Dia nggak punya apa-apa gitu ya. $\mathrm{Na}$ itu aa kakak saya nomor satu. Tapi itu jadi panutan saya, terutama saya, karna saya tinggal dengan kehidupan keras ya, dalam arti dia punya anak empat yang empat-empatnya sukses, yang paling kecil dia di Amerika skarang. Aa.. apa? Kehidupannya tuh kehidupan, kehidupan miskin gitu. Kehidupan nggak punya. Jadi kami kalo punya uang tuh hanya bisa aa bisa untuk minum susu segelas barangkali. Itu minum susu segelas juga sulit nyarinya ya? Dengan makan yang tidak seperti sekarang ya. Jadi kami itu makan semua dibagi ya. Jadi piring-piring tu dibagi oleh ibu saya. Piring-piring-piring isinya $t u$ ada kentang dua biji, dua biji, dua biji gitu, nggak boleh nambah gitu lo. Nggak bole nambah sama sekali. Dan kakak saya paling besar ini, yang, yang di fakultas kedokteran, kan dia masih kuliah itu, ngambil jeroan ah apa tuh, yang dibuang di, di kali, di got gitu, dibuang, diambil sama dia disikat gitu lo. Disikat untuk dimasak gitu ya? Itu dikasih ke ibu saya. Ibu saya masak lalu dibagi-bagi ke adik-adiknya gitu. Ke anak-anaknya. Aa kehidupan kami bener-bener sangat, sangat ee miskin gitu, nggak punya pa-pa. Lalu aa itu, itu pada diri saya juga ada sifat untuk bageimana supaya bisa. Tapi satu hal yang pasti itu bahwa kami dididik untuk belajar. Sekolah gitu, karna sekolah tu nomor satu. Nggak boleh nggak, ya. Walopun dengan mengemis, minta-minta untuk ee masuk sekolah gitu, tidak aa anak kan harus bayar. Dan... lalu stela itu udah, saya tinggal sama kakak saya itu, ee nggak ee agak lama sedikit. Setelah itu dia mulai karirnya maju dan sebagainya, mulai kita dibantu ee uang kuliah, uang sekolah, gitu ya. Uang kuliah saya dapet uang skola, kuliah, sehingga waktu saya dapet beasiswa Supersemar dari Pak Harto itu, saya tu ee uang, uang sekolah saya tetep dibayarin karna uang Supersemar itu adalah uang saya gitu lo. Jadi katanya, 'Itu kan jerih payah kamu. IP kamu kan, apa? 'nilai kamu kan tinggi, jadi kamu dapet, itu hak kamu,' gitu. Tetep aja saya dikasi tuh. Saya inget saya dapet lima belas ribu dari Pak Harto, dari Supersemar. Jadi mulai pertama kali saya kulia tuh saya ditawari karna aa stela semester satu tu nilai saya cukup baik yah, bagus-bagus, lalu saya ditawari saya dapet Supersemar.

\section{Total word count: 816. CI words: 126}

\section{Data sample AV8}

AV8, the data set with CI content above $>0.7$, is the transcript of a comedy scene from a film starring the late legendary Betawi actor Benjamin. In this comedy scene, Benjamin and his friend are crossing a river and are arguing over the dirty water and how his friend who is being dragged on a sled because he is ill, will have to get partly submerged while Benjamin is riding a horse. Benjamin's Betawi cultural background reflects the heavily $\mathrm{CI}$ influenced informal register. CI items are in italics.

Ben, pelan-pelan dong you jalanye, aye sedang meriang nih, Ben... brengsek lu ah

ah...diem-diem aja lu di situ, molor aja terus, lu taunya sampe, ah...pake meriang segala, udah tau orang mau ngungsi, mau ngikut, jage diri lu baek-baek, gue nga buang aja udah bagus lu...ah.let's go aduh Ben...Ben...tobat ah...aye bisa mati di jalanan nih...aduh...

\section{slowly...slowly tiger...slowly}

Ben..Ben..plosotan Ben...pelan pelan Ben...aduh aduh aduh...bisa nyangkut nih aye....Ben...mau dibawa kemana sih Ben...Ben...mau ke mana?

Sorry dongo...memang nasib lu...c'mon tiger...mudah-mudahan nga dicaplok buaya lu pake lewat sungai lagi...aduh...dingin...aye sedang meriang nih...Ben...kira-kira dong...kau kira aku ini ikan kapus...Ben...apaan tuh?... pada ngambang nih gituan...Ben... lekasan dong

shut up! Merendem aja situ terus...ama gituan aja takut...bencet aja... ah... masa nga ancur...eh ngorok aja situ terus 
Ben, pelan-pelan dong you jalanye, aye sedang meriang nih, Ben... brengsek lu ah ah...diem-diem aja lu di situ, molor aja terus, lu taunya sampe, ah...pake meriang segala, udah tau orang mau ngungsi, mau ngikut, jage diri lu baek-baek, gue nga buang aja udah bagus lu...ah..let's go aduh Ben...Ben...tobat ah... aye bisa mati di jalanan nih...aduh... slowly...slowly tiger...slowly

Ben..Ben..plosotan Ben...pelan pelan Ben...aduh aduh aduh...bisa nyangkut nih aye....Ben...mau dibawa kemana sih Ben...Ben...mau ke mana?

Sorry dongo...memang nasib lu...c'mon tiger...mudah-mudahan nga dicaplok buaya lu pake lewat sungai lagi...aduh...dingin...aye sedang meriang nih...Ben...kira-kira dong...kau kira aku ini ikan kapus...Ben...apaan tuh?... pada ngambang nih gituan...Ben... lekasan dong

shut up! Merendem aja situ terus...ama gituan aja takut...bencet aja... ah... masa nga ancur...eh ngorok aja situ terus

Total word count: 236 . CI words (in italics): 175 